\title{
PENGEMBANGAN KEPROFESIAN BERKELANJUTAN (PKB) BAGI GURU MELALUI PROGRAM INDUKSI GURU PEMULA (PIGP)
}

\author{
Arsyad \\ Dsoen Tetap STKIP Muhammadiyah Bogor \\ Arsyad2006@yahoo.com
}

\begin{abstract}
Abstrak
Melalui kegiatan pengembangan kompetensi dan profesional berkelanjutan atau continuing competence and professional development (CCPD) akan terwujud guru kompeten dan profesional yang bukan hanya sekedar memiliki ilmu pengetahuan yang kuat, tuntas dan tidak setengah-setengah, tetapi tidak kalah pentingnya juga memiliki kepribadian yang matang, kuat dan seimbang. Dengan penguasaan ilmu pengetahuan dan teknologi yang kuat, tuntas dan tidak setengah-setengah serta kepemilikan kepribadian yang prima, maka diharapkan guru terampil membangkitkan minat peserta didik kepada ilmu pengetahuan dan teknologi melalui penyajian layanan pendidikan yang bermutu. Model pengembangan kompetensi dan profesional berkelanjutanyang sudah ada, yaitu program induksi guru pemula (PIG). Kegiatan PIG sebagai proses pembelajaran bagi guru pemula agar para guru pemula tersebut dapat segera beradaptasi dengan iklmi kerja dan budaya sekolah dan dapat bekerja sebagai guru professional di sekolah, pelaksanaan induksi guru pemula meliputi;persiapan; (2) pengenalan sekolah/madrasah dan lingkungannya; (3) pelaksanaan dan observasi pembelajaran;(4) penilaian; dan pelaporan.
\end{abstract}

Kata Kunci; Keprofesian berkelanjutan, kompetensi dan professional, program induksi guru pemula.

\section{A. Pendahuluan}

Indonesia menghadapi tantangan yang lebih serius dalam melaksanakan pembangunan ke depan khususnya pembangunan pada sumber daya manusia (SDM) yang berkulaitas. Tantangantantangan tersebut adalah; pertama, bahwa dalam rentang tahun 2010-2045, Indonesia mendapatkan berkah demografi, dan sejak tahun 2010 penduduk Indonesia dalam rentang usia 09 tahun mencapai 45.9 juta, sementara usia 11-19 tahun mencapai 43.55 juta. Artinya bahwadalam rentang tahun 2010-2045 jumlah penduduk Indonesia dengan usia produktif sangat melimpah,dan merekalah generasi emas yang bakal menjadi generasi penerus bangsa ini; kedua, tuntutan untuk memenuhi komitmen global dalam rangka pencapaian sasaran-sasaran Millenium 
Development Goals (MDGs), Education For All (EFA), dan Education for Sustainable Development (EfSD;.ketiga, pemerintah juga dituntut untuk menerapkan Standar Nasional Pendidikan dengan menekankan keseimbangan antara olah pikir, olah rasa, olah hati, dan olahraga; keempat, mengembangkan kebijakan yang kondusif untuk menghasilkan perguruan tinggi berdaya saing global (World Class University/WCU), sehingg dapat meningkatkan kemitraan yang sinergis dengan dunia usaha dan industri, organisasi masyarakat, dan organisasi profesi; kelima, tantangan dalam mengembangkan kebijakan pemberdayaan tenaga pendidik dan kependidikan dengan memperhatikan profesionalisme.

Indikator suatu bangsa sangat ditentukan oleh tingkat sumber daya manusianya dan indikator sumber daya manusia ditentukan oleh tingkat pendidikan masyarakatnya. Semakin tinggi sumber daya manusianya, maka semakin baik tingkat pendidikannya, dan demikian pula sebaliknya. Oleh sebab itu indikator tersebut sangat ditentukan oleh guru, tanggungjawab menjalankan amanahprofesi yang diembannya, dan rasa tanggungjawab moral merupakan indikator profesionalisme seorang guru Semua itu akan terlihat kepada kepatuhan dan loyalitasnya di dalam menjalankan tugas keguruannya di dalam kelas dan tugas kependidikannya di luar kelas. Sikap ini akan dibarengi pula dengan rasa tanggungjawabnya mempersiapkan segala perlengkapan pengajaran sebelum melaksanakan proses pembelajaran. Di samping itu, kemampuan dalam menerapkan metodologi pembelajaranm yang bervariatif, disertai dengan media dan evsluasi pembelajaran yang tepat, merupakan bagian dari gambaran keprofesionalan guru dalam menajalankan tugasnya.

\section{B. Pengembangan Keprofesian Guru Melalui Induksi Guru Pemula (PIG)}

Guru sebagai salah satu komponen dalam pendidikan harus ditingkatkan terus kompetensi dan ketrampilannya untuk menghasilkan proses pembelajaran yang bermutu kelas. Salah satu persoalan tentang guru adalah masih banyak guru yang belum mampu mengembangka dan menerapkan metodologi pembelajaran yang menarik, bervariasi sesuai dengan bidang atau topik dan usia peserta didik, dan juga masih banyak guru yang mangkir atau tidak hadir di kelas tanpa alasan yang jelas.Kompetensi guru mengajar tentunya memberikan dampak terhadap aspek kualitas kegiatan proses pembelajarannya.Penguasaan materi seorang guru sangat berpengaruh dalam meningkatkan mutu proses pembelajarn di kelas. Permasalahan yang menyangkut 
kompotensi guru dalam proses pembelajaran sangat terkait dengan penguasaan atau kompetensi guru dalam melaksanakan dan mengefektifkan proses pembelajaran di kelas.

Melalui undang-undang Nomor 14 tahun 2005 tentang Guru dan Dosen pasal 7 mengamanatkan, bahwa guru sebagai tenaga yang professionalwajib memiliki kualifikasi akademik, kompetensi, dan sertifikat yang sesuai dengan kewenangan mengajar. Pasal 9 juga menyatakan bahwa kualifikasi akademik sebagaimana dimaksud diperoleh melalui pendidikan tinggi jenjang S-1/D-IV. Hal tersebut lebih ditegaskan pada Peraturan Pemerintah RI. Nomor 19 Tahun 2005 tentang Standar Nasional Pendidikan Pasal 29 yang menyatakan bahwa pendidik pada pendidikan anak usia dini (PAUD), SD/MI, SMP/Mts, SMA/MA, SDLB/SMPLB/SMALB dan SMK/MAK masing-masing memiliki:

1. Kualifikasi akademik minimal S-1/D-IV;

2. Latar belakang pendidikan tinggi yang sesuai dengan mata pelajaran yang diampu;

3. Sertifikat profesi pendidik sesuai dengan peruntukannya.

Dalam UU N0. 14 tahun 2005 tersebut mengamanatkan bahwa guru wajib memiliki kualifikasi, kompetensi, sertifikat pendidik, sehat jasmani dan rohani, serta memiliki kemampuan untuk mewujudkan tujuan pendidikan nasional. Guru yang sudah memiliki kualifikasi akademik S-1 atau D-IV dan lulus dalam uji kompetensi, akan mendapatkan sertifikat sebagai pendidik dan dinyatakan sebagai guru professional.

Berdasarkan undang-undang nomor 14 tahun 2005tentang guru dan dosen pada pasal 32 menjelaskan tentang pembinaan dan pengembangan guru, yaitu pasal 32 (1) Pembinaan dan pengembangan guru meliputi pembinaan dan pengembangan profesi dan karier. Pada pasal (3) UU. Nomor 14 tahun 2005tentang guru dan dosen tersebut, dijelaksan bahwapembinaan dan pengembangan profesi guru sebagaimana dimaksud pada ayat (1) dilakukan melalui jabatan fungsional.Pada pasal 33 dijelaskan bahwa kebijakan strategis pembinaan dan pengembangan profesi dan karier guru pada satuan pendidikan yang diselenggarakan oleh Pemerintah, pemerintah daerah, atau masyarakat ditetapkan dengan Peraturan Menteri.

Pemerintah menyadari betul bahwa selama ini mutu guru di Indonesia pada umunya masih rendah, antara lain rendah dari segi kualifikasi akademik, masih banyak yang belum sarjana (S.1) juga rendahnya kompetensi guru, hal ini tentu akan berpengaruh pada rendahnya mutu pendidikan secara nasional. Dengan rendahnya mutu guru tersebut, lalu pemerintah mengeluarkan kebijakan untuk meningkatkan mutu guru dengan menjadikan guru sebagai tenaga 
professional melalui peningkatan kualifikasi akademik, kompetensi dan lalu ditandai dengan sertifikat pendidik.

Salah satu bentuk pengembangan dan peningkatan mutu guru, terutama dalam memahami dan mengimplementasikan empat kompetensi wajib guru adalah guru pemula atau golongan III/a yang baru diangkat harus melalui induksi guru pemula. Program induksi ini juga telah dilakukan oleh negara-negara yang memiliki pendidikan yang maju, seperti Inggris, USA dan Australia. Program induksi di Inggris adalah Mandatory Induction Program, untuk seluruh guru pemula yang kualified,tidak dapat diangkat sebagai pegawai jika tidak memenuhi persyaratan memuaskan dalam induksi. Di USA (Massachusetts) bahwasemua sekolah harus memiliki program induksi untuk seluruh guru-guru di tahun pertama. Sementara di Australia bahwakewajiban profesional untuk mendukung guru pemula yang dimuat dalam kebijakan pengembangan profesional guru.

Kegiatan induksi guru pemula pertama; sebagai orientasi. Guru pemula sebelum diberikan tugas-tugas mengajar mereka harus diberikan orientasi untuk memamhami tugas dan tanggung jawab sebagai seorang guru. Kedua; sebagai bentuk pelatihan di tempat kerja, proram indukdi bagi guru pemula menjadi prooses latihan dan belajar menjadi guru yang sesungguhnya. Ketiga; sebagai pengembangan. Guru pemula harus mengetahui pola dan model untuk mengembangkan diri sebagai guru yang professional. Keempat; sebagai sarana untuk praktik pemecahan permasalahan dalam proses pembelajaran. Melalui pendampinganoleh para pembina, guru senior, maka peserta program induksi guru pemula belajar untuk memecahkan permasalahan dalam proses pembelajaran di sekolah.

Sebagai proses pembelajaran bagi guru pemula agar para guru pemula tersebut dapat segera beradaptasi dengan iklmi kerja dan budaya sekolah dan dapat bekerja sebagai guru professional di sekolah, pelaksanaan induksi guru pemula, berdasarkan Permendiknas RI N0. 27 tahun 2010, meliputi;persiapan;pengenalan sekolah/madrasah dan lingkungannya;pelaksanaan dan observasi pembelajaran;penilaian; dan pelaporan. Lebih lanjut dalam Permendiknas RI N0. 27 tahun 2010 tersebut bahwa program Induksi adalah kegiatan orientasi, pelatihan di tempat kerja, pengembangan, dan praktik pemecahan berbagai permasalahan dalam proses pembelajaran bagi guru pemula pada satuan pendidikan di tempat tugasnya. Dengan demikian, bahwa induksi guru pemula menjadi sebuah proses orientasi bagi guru dalam mengajar dan menjadi pembelajaran untuk menjadi guru yang profesional di tempat kerja selama tahun pertama mengajar.Hal ini 
merupakan tahap awal dalam Pengembangan Keprofesian Berkelanjutan (PKB) seorang guru. Program Induksi dirancang secara sistematis dan terencana berdasarkan konsep kerjasama dan kesejawatan antara guru pemula, guru pembimbing, guru sejawat, kepala sekolah, dan pengawas dengan pendekatan pembelajaran profesional. Tujuan program induksi adalah memberikan dukungan bagi guru pemula dan sebagai pengembangan profesi berkelanjutan, Meningkatkan kinerja dan efektifitas guru pemula untuk meningkatkan prestasi belajar siswa.

Pada pasal 3 permendiknas RI N0. 27 tahun 2010, bahwa penyelenggaraan program induksi bagi guru pemula didasarkan pada prinsip-prinsip sebagai berikut: (1) profesional; penyelenggaraan program yang didasarkan pada kode etik profesi, sesuai bidang tugas; (2) kesejawatan; penyelenggaraan atas dasar hubungan kerja dalam tim; (3) Akuntabel; penyelenggaraan yang dapat dipertanggungjawabkan kepada publik; (4) berkelanjutan, dilakukan secara terus menerus dengan selalu mengadakan perbaikan atas hasil sebelumnya.

\section{Kesimpulan}

Dari gambaran tentang program indukasi tersebut diatas, bahwa program induksi guru pemula dilaksanakan dalam rangka menyiapkan guru pemula agar menjadi guru profesional dalam melaksanakan tugas-tugas proses pembelajaran. Melalui program induksi guru pemula diharapkan dapat meningkatkan kemampuan dan keterampilan untuk menjadi guru yang sesungguhnya dalam melaksanakan proses pembelajaran, sehingga dapat peningkatan mutu pendidikan sekaligus memecahkan permasalahan yang dihadapi dan dialami oleh guru pemula dalam pelaksanaan tugas sehari-hari sesuai dengan karakteristik mata pelajaran, peserta didik, kondisi sekolah, dan lingkungannya. Hasil pelaksanaan induksi guru pemula selama satu tahun atau lebiha, guru pemula tersebut akan mendapatkan rekomendasi dari kepala dinas pendidikan atau kepala kemenag, sebagai bukti telah dilaksanakan proses pendampingan dan dapat dianggap layak untuk menjadi guru.

Untuk mengimplementasikan permendiknas RI. N0. 27 tahun 2010 tersebut, dinas pendidikan Kabupaten harus melakukan beberapa kegiatan dalam rangka implementasi program induksi guru pemula sesuai dengan permendiknas. Kegiatan yang dilakukan meliputi;

1. Sosialisasi program pelaksanaan induksi guru pemula bagi kepala sekolah, pengawas sekolah dan guru-guru pembimbing

2. Melakukan pendataan peserta program induksi guru pemula 
3. Pelaksanaan kegiatan program induksi guru pemula

4. Monitoring dan evaluasi (M\&E) pelaksanaan program induksi guru pemula.

Beberapa Kabupaten terutrama yang telah telah melakukan Mitra pada Program BERMUTU tahun 2010, melalui dinas pendidikan kabupaten melaksanakan program induksi guru pemula tahap pertama dengan hasil kegiatan sebagai berikut;

1. Peserta program induksi guru pemula terdiri dari; (a) Guru SD sebanyak, (b) Guru SMP sebanyak, (b) Guru SMA/SMK sebanyak

2. Pengangkatan Guru Pembimbing, pengawas di sekolah tempat pelaksanaan indukdi guru pemula.

Dari gambaran pelaksanaan program induksi kabupaten Ciamis tersebut, memperlihatkan bahwa program induksi sangat membantu para guru pemula dalam melaksanakan tugas-tugas sebagai guru.

\section{Referensi}

Arsyad, Arsyad., \& Sulfemi, Wahyu Bagja. Pengaruh Persepsi Guru Tentang Kemampuan Manajerial Kepala Sekolah dan Kecerdasan Emosional Guru Terhadap Kinerja Guru (Studi Kasus Di SMK Muhammadiyah 6 Kabupaten Bogor). Fascho 2 (1), 1-9. 2013.

Arsyad, Arsyad, \& Sulfemi, Wahyu Bagja. (2014). Minat Siswa Tentang Keadministrasian dengan Hasil Belajar Administrasi Perkantoran. Edutecno 9 (2), 40-50

Arsyad, Arsyad. Pengembangan Keprofesian Berkelanjutan (PKB) Bagi Guru Melalui Program Induksi Guru Pemula (PIGP) Prosiding Seminar Nasional, 1 (1). 36-41. 2016.

Marimba, Ahmad, Pengantar Filsafat Pendidikan Islam, Bandung ; Al-Ma;Arif, 1990.

Fajartriani, Tia., \& Sulfemi, Wahyu Bagja. Pengaruh Motivasi Kerja Guru dan Iklim Organisasi Terhadap Kinerja Guru SMA Negeri di Kecamatan Cigudeg. Edutecno. 8 (1), 17-26. 2014.

Hasan Langgulung, Asas-Asas Pendidikan Islam, Jakarta : Pustaka Al-Husna, 1987, Cet. Ke-7.

Hasbullah, Dasar-Dasar Ilmu Pendidikan, Jakarta: Raja Grafindo Persada, 2005, Cet Ke-4.

Muhammad Fadhil Al-Jamālī, Filsafat Pendidikan Dalam Al-Qur'an, Surabaya: Bina Ilmu, 1986.

Nasution Harun, Akal Dan Wahyu Dalam Islam, Jakarta : UI Press, 1992, Cet. Ke-3.

Nurcholish Madjid, Masyarakat Religius, Jakarta: Paramadina, 2000. 
Randy R. W. Dan Riant Nugroho, 2007. Manajemen Pemberdayaan, Jakarta : PT Elex Media Komputindo, 2007.

Sulfemi, Wahyu Bagja. Pengaruh Persepsi Siswa Atas Kemampuan Pedagogik Guru Dan Motivasi Belajar Siswa Terhadap Prestasi Belajar Ilmu Pengetahuan Sosial Siswa (Survei Di SMK Swasta Kabupaten Bogor). Edutecno. 7 (2), 17-26. 2013.

Sulfemi, Wahyu Bagja. Pengaruh Motivasi dan Lingkungan Sekolah Terhadap Prestasi Belajar Sejarah Di SMA Negeri Leuwilang Kabupaten Bogor. Fascho: Kajian Pendidikan Dan Sosial Kemasyarakatan 9 (2), 42-52. 2014.

Sulfemi, Wahyu Bagja. Pengaruh Metode Pembelajaran Kontekstual dan Penggunaan Media Video Pendidikan Terhadap Hasil Belajar IPS. Edutecno 13 (2), 1-10. 2015.

Sulfemi, Wahyu Bagja. Challenges Of Indonesian Teacher Competence In Dealing With Asean Economic Cummunity (AEC). Engglis Forum. 1 (1). 69-79. 2015.

Sulfemi, Wahyu Bagja. Kemampuan Pedagogik Guru. Prosiding Seminar Nasional. STKIP Muhammadiyah Bogor 1. (1). 71-83. 2015.

Sulfemi, Wahyu Bagja. Modul Pembelajaran Ilmu Sosial Dan Budaya Dasar. Bogor : STKIP Muhammadiyah Bogor. 2016.

Sulfemi, Wahyu Bagja. Perundang-Undangan Pendidikan. Bogor : Program Studi Administrasi Pendidikan STKIP Muhammadiyah Bogor. 2016.

Purwanto Ngalim, Ilmu Pendidikan Teoritis Dan Praktis, Bandung : PT. Rosdakarya, 1994, Cet. $\mathrm{Ke}-7$

Zakiyah Darajdat, Ilmu Pendidikan Islam, Jakarta: Bumi Aksara, 1992, Cet. Ke-2.

Wardiman Djojonegoro, Pengembangan Sumber Daya Manusia Melalui SMK, (Jakarta: PT. Balai Pustaka, 1999.

Yusfiriadi, Yusfitriadi., \& Sulfemi, Wahyu Bagja. Penyelewangan Dana Dalam Dunia Pendidikan. Fascho 1 (1), 1-9. 2012. 